\title{
Corporate social responsibility, mining and sustainable development in Namibia: critical reflections through a relational lens
}

Article

Accepted Version

Littlewood, D. (2015) Corporate social responsibility, mining and sustainable development in Namibia: critical reflections through a relational lens. Development Southern Africa, 32 (2). pp. 240-257. ISSN 1470-3637 doi:

https://doi.org/10.1080/0376835X.2014.984833 Available at https://centaur.reading.ac.uk/38508/

It is advisable to refer to the publisher's version if you intend to cite from the work. See Guidance on citing.

To link to this article DOI: http://dx.doi.org/10.1080/0376835X.2014.984833

Publisher: Taylor \& Francis

All outputs in CentAUR are protected by Intellectual Property Rights law, including copyright law. Copyright and IPR is retained by the creators or other copyright holders. Terms and conditions for use of this material are defined in the End User Agreement.

www.reading.ac.uk/centaur 
Central Archive at the University of Reading

Reading's research outputs online 
Cite as: Littlewood, D. (2015) Corporate social responsibility, mining and sustainable development in Namibia: Critical reflections through a relational lens, Development Southern Africa, DOI:10.1080/0376835X.2014.984833

\title{
Corporate social responsibility, mining and sustainable development in Namibia: Critical reflections through a relational lens
}

\author{
Dr David Littlewood \\ Lecturer in Reputation and Responsibility, Henley Business School, \\ Greenlands Campus, Henley-on-Thames, \\ Oxfordshire, RG9 3AU, UK. \\ Tel: +44 (0) 1491414559. \\ Email: d.c.littlewood@reading.ac.uk
}

For its advocates Corporate Social Responsibility (CSR) represents a powerful tool through which business and particularly multinationals can play a more direct role in global sustainable development. However for its critics CSR rarely goes beyond business as usual, and is often a cover for business practices with negative implications for communities and the environment. This paper explores the relationship between CSR and sustainable development in the context of mining in Namibia. Drawing upon extant literatures on the geographies of responsibility, and referencing in-country empirical case study research, a critical relational lens is applied to consider their interaction both historically and in the present.

Keywords: Mining; Corporate Social Responsibility (CSR); Sustainable Development; Namibia; Southern Africa; Geographies of Responsibility.

\section{Introduction}

To mark the two decades anniversary of the 1992 Rio Earth Summit delegates from around the world recently gathered for the United Nations Rio +20 Conference on Sustainable Development. The original Rio conference was the first major event of its type specifically addressing the themes of development and the environment, and was unprecedented in the global media coverage it received and world leaders in attendance. It was also a watershed moment in how business was viewed in relation to global sustainable development challenges. In the Summit's wake it was increasingly suggested that through Corporate Social Responsibility (CSR) business could play a more meaningful role in tackling social and environmental 
problems. Over the intervening years this idea has been embraced by governments, international institutions, business leaders and some sections of civil society (Ely et al., 2013).

Nevertheless, the potential of CSR as a vehicle for sustainable development at global but also national and local scales remains contested. CSR advocates argue that it represents an important avenue through which business can contribute to addressing 'wicked problems' (Rittel \& Webber, 1973). They suggest that there is a 'business case' for such engagement (Carroll \& Shabana, 2009), with 'win-win' or 'shared value' (Porter \& Kramer, 2011) creating opportunities available to businesses that innovate to solve social, environmental or poverty alleviation issues (London \& Hart, 2010). However, criticism of CSR persists, with opponents countering that it still rarely goes beyond business as usual (Banerjee, 2008), that a host of issues are ignored in prevailing CSR agendas and discourses, particularly in relation to the developing world, with CSR viewed as at best a public relations exercise and at worst 'greenwash' for irresponsible behaviour (Terrachoice, 2014).

Discussions in this paper engage with these wider ongoing debates through exploration of the nexus of CSR and sustainable development in the mining industry in Namibia. Their historic and contemporary interaction is critically examined through a relational lens informed by writing on the geographies of responsibility (Massey, 2004). This paper draws upon empirical case study research with four mining companies operating in Namibia, with discussions structured around the following research questions: (1) Mining activity in Namibia occurs within a complex web of relationships (e.g. state/firm relationships, relationships with communities, employees and the environment), historically and in the present how congruent are these relationships with sustainable development? (2) How can and what is the benefit of applying a relational lens to the study of CSR in the mining industry in Namibia and more widely?

This paper contributes to scholarship, knowledge and practice in three major areas. (1) It adds to hitherto limited work on CSR and sustainable development in the context of mining in Namibia, and Africa more widely. Much of the extant literature on CSR and mining/resource extraction in Africa has focussed on the Continent's larger countries e.g. South Africa and Nigeria. This study therefore has potentially greater salience for other countries on the Continent. (2) In applying relational perspectives from human geography to CSR, this paper also makes a more interdisciplinary scholarly contribution, including reflection of how such relational perspectives compliment more relational theories of CSR in management e.g. stakeholder theories (Secchi, 2007). (3) Given the ongoing expansion in mining across Africa, as well as the historical significance of resource extraction to the economies of so many African countries, there is an 
imperative for more policy and practitioner relevant research of the kind presented in this paper.

\section{Mining, CSR and Sustainable Development}

CSR has been described and defined in a variety of ways by disparate global actors (Carroll, 1999), yet there remains a lack of consensus around its meaning (Lindgreen \& Swaen, 2010). In this paper, while recognising these ongoing definitional ambiguities, CSR is utilised as an overarching term to describe engagements by mining companies with sustainable development issues complying with and on a voluntary basis going beyond legal requirements. CSR encompasses the totality of a company's interactions with sustainable development throughout its value chains and in its relationships.

Few industries are as controversial, have attracted as much critical attention, and are as significant to developing nation economies, as mining. For mining advocates, natural resources are a blessing and can act as a springboard for national economic growth and sustainable development (see ICMM, 2014, and its Resource Endowment initiative). For its critics, mining is associated with spectacularly unequal distributions of wealth, conflict and negative environmental impacts (Bebbington et al., 2008). The relationship between mining and sustainable development is complex and contentious (Hamann, 2003). Discussion of mining's role in global sustainable development is ongoing (Mason et al., 2011), while at a national level debate continues in relation to the 'resource curse' effects of natural resource abundance (Williams, 2011). At a local level ensuring host communities and indigenous groups benefit from mining, while avoiding its negative effects during and after operations, remains a key concern (Cronje \& Chenga, 2009).

The mining industry has been at the forefront of business engagement with CSR. This can be at least partially attributed to the controversial nature of many mining investments and the social and environmental problems that so often seem to accompany mining activity. That mining has been at the CSR vanguard also reflects the fact that it increasingly takes place in the developing world, in countries with weak governance, legislation and institutional capacity (Kolk \& Lenfant., 2012). Within the growing body of literature on mining, CSR and sustainable development, significant themes include: community sustainability (Owen \& Kemp., 2012); environmental practices (Wan, 2014); governance and the political economy of mining investment (Prno \& Slocombe, 2012); and the effectiveness of local development interventions (Campbell, 2012). While much early work on mining, CSR and sustainable development viewed their relationship quite sceptically, more recent studies have noted that at least some companies have improved their sustainable development performance, particularly through more strategic approaches 
and innovative multi-stakeholder partnerships (Kolk \& Lenfant, 2012).

There is a growing body of work exploring mining, CSR and sustainable development in Africa. In relation to Southern Africa this work has often focussed on South Africa (Kapelus, 2002; Hamann, 2004; Cronje \& Chenga 2009; Campbell, 2012), although studies have also examined other countries in the region including Zambia (Lungu, 2008); Botswana (ICMM, 2014), and the Democratic Republic of the Congo (Perks, 2012), as well as cross country comparison (Hamann \& Kapelus, 2004). CSR, sustainable development and the mining industry in Namibia have also received some attention. For example state/ firm relations before and after independence (Kempton \& Du Preez, 1997), the intersection of responsibility and legitimacy with reference to the activities of De Beers (Classen \& Roloff, 2011); and issues of CSR and mining community sustainability (Littlewood, 2013). CSR, mining and sustainable development in Namibia has also been explored using single case studies (Karamata, 2008). Finally there is a body of practitioner and corporate literature to draw upon, with the mining industry in Namibia a frequent subject of discussion in national media. Nevertheless, an overarching historical and theoretically informed examination of CSR, mining and sustainable development in Namibia has yet to be undertaken.

\section{Sustainable Development and Relational Responsibility}

Like CSR, sustainable development is a term that has been widely described and defined. Discussions of its meaning often begin with reference to the Bruntland Commission publication Our Common Future (WCED, 1987) and a paraphrasing of 'sustainable development is development that meets the needs of the present without compromising the ability of future generations to meet their own needs' (Seuring et al 2003). However, as explored by Barkemeyer et al (2014), in the original Bruntland report the concept of sustainable development was considerably expanded from this. Two key elements of the full Bruntland definition were the concept of 'needs' and in particular the essential needs of the world's poor to which overriding priority should be given, and the idea of 'limitations' in resources and the earth's carrying capacity, necessitating trade-offs between economic, social and environmental imperatives. Through quantitative analysis of influential CSR policy documents (e.g. the UN Global Compact Principles), Barkemeyer et al (2014) chart a shift in global sustainable development discourse and priorities between 1987 and present, and find an increasing prioritisation of environmental concerns (northern priorities) over those of development (southern priorities), and little acknowledgement of limits and trade-offs. They link this to an emphasis on the 'win-win' paradigm and making sustainable development, or sustainability, more acceptable for mainstream (particularly business) audiences. The definition of sustainable development adopted in this paper embraces the original and full Bruntland version, with its human centric 
pro-poor emphasis.

The relational lens adopted draws upon work in human geography proposing more relational understandings of responsibility (Massey, 2004), but also relational theories of CSR in management (Secchi, 2007) e.g. stakeholder theories. Over the last two decades, and reflecting a wider 'moral turn' in geography as a discipline (Smith 1997), the subject of responsibility has received growing attention. Early contributions to the field, somewhat uncritically, asserted the responsibility of richer nations and their citizens to 'distant others' e.g. the underprivileged peoples and nations of the developing world (Corbridge 1998). However, Massey's (2004) work Geographies of Responsibility represented a significant development in these debates and a shift away from uni-linear understandings of responsibility towards ones which were more power conscious, relational and recognising of the mutual constitution of sometimes distant places and peoples. Noxolo et al (2011) review various strands of more recent responsibility writing, including, and most relevant to this study: work on responsibility to future generations, especially in relation to the environment (Armstrong, 2006); work exploring responsibility as postcolonial relationality (Power, 2009); and those addressing responsibility embedded in political notions (Atkins et al., 2006).

Insights from this extant literature frame discussions in this paper. Accordingly, mining companies, and historic and contemporary mining activity in Namibia is conceived as occurring within and through relationships e.g. between firms and communities, state and non-state, human and non-human actors. Spatially these relationships extend beyond local social, environmental and economic interactions and impacts e.g. in 'host' communities, and entail reflection on the wider implications of mining activity for sustainable development across Namibia. Responsibility's temporal dimensions are also identified entailing reflection on the historical activities of mining companies in Namibia, the present day implications and legacies of those practices, and the consequences of current activities for future generations. There is considerable complementarity between the framing proposed and relational theories of CSR, particularly stakeholder theories focusing on affective firm stakeholder/relationships. Nevertheless this paper eschews a purely stakeholder lens, which can sometimes be quite company centric and instrumental.

\section{Methodology}

This paper is based on a study carried out from 2007-11, with data collection primarily occurring during 2008-09, but subsequent monitoring and analysis of developments across the industry. Four case study mining companies were examined, with the approach informed by writing on 
case study research and methodologies (Yin, 2009). Background on the four case studies is provided in Table 1. Qualitative research methods were primarily employed, with semi structured interviews the principal method of data collection. Interviews were conducted with representatives of key informant groups including: company staff; national, regional and local government representatives; local service providers; community and civil society representatives; NGOs; employee representatives; and beneficiaries. Access was negotiated with the case study companies but also with wider stakeholders. Local facilitators/gatekeepers inside and outside companies played a significant role in identification and recruitment of participants. In total 90 interviews were undertaken, predominantly in English but with respondents given the choice of a translator if preferred. Where possible, interviews were recorded. A semi-structured approach was used (Kitchen and Tate 2000), and flexibility was adopted in the wording, order and whether questions were asked. Interviews were conversational and exploratory, but informed by the aims of the research. An interview guide was used to kick start conversation where necessary, to retain structure, and to ensure interviews did not stray off topic.

\section{Table 1. Case Study Descriptions}

\begin{tabular}{|c|c|c|}
\hline Case Study & Description & Key elements of CSR engagement \\
\hline Namdeb & $\begin{array}{l}\text { Location: Sperrgebiet and } \\
\text { Oranjemund Karas Region. } \\
\text { Background: } 1994 \text { joint } \\
\text { venture De Beers and } \\
\text { Government of Namibia, } \\
\text { prior to that Consolidated } \\
\text { Diamond Mines (CDM) } \\
\text { which has operated in } \\
\text { Namibia since 1920s. }\end{array}$ & $\begin{array}{l}\text { Namdeb Foundation established in 2010, } \\
\text { amalgamation of previous arrangements } \\
\text { (Chairman's Fund during CDM period, then the } \\
\text { Namdeb Social Fund, Namdeb Employees Social } \\
\text { Responsibility Fund, Oshipe Development Fund); } \\
\text { OSHAS18001 safety certification; environmental } \\
\text { clearance certificates; Affirmative action plan } \\
\text { approved; peer educator and wellness } \\
\text { programmes; Namibian government 50\% } \\
\text { shareholding. De Beers Marine Namibia also has } \\
\text { OHSAS 18001 and ISO14001 accreditation, } \\
\text { approved affirmative action plan, engages in } \\
\text { philanthropy; Government shareholding. }\end{array}$ \\
\hline $\begin{array}{l}\text { Skor } \\
\text { Zinc }\end{array}$ & $\begin{array}{l}\text { Location: Rosh Pinah, Karas } \\
\text { Region } \\
\text { Background: Construction } \\
\text { began 1999 operations } \\
\text { commenced 2001. Originally } \\
\text { owned by Anglo-American } \\
\text { and from 2010 Vedanta } \\
\text { Resources Plc }\end{array}$ & $\begin{array}{l}\text { Previous owners Anglo American continue to } \\
\text { provide social investment through the Anglo } \\
\text { American Namibia Foundation (AANF) } \\
\text { established in 2009, prior to that more ad hoc } \\
\text { support. Substantial investment in community } \\
\text { infrastructure during Anglo period e.g. pre- } \\
\text { primary school, clinic, sports field. Current } \\
\text { owners Vedanta have: ISO14001 accreditation; } \\
\text { OHSAS } 18001 \text { health and safety accreditation; } \\
\text { approved affirmative action plan; provides } \\
\text { bursaries and ad hoc community investment and } \\
\text { through the global Vedanta Foundation; Peer } \\
\text { educator and wellness programmes. }\end{array}$ \\
\hline $\begin{array}{l}\text { Rössing } \\
\text { Uranium }\end{array}$ & $\begin{array}{l}\text { Location: Arandis, Erongo } \\
\text { Region }\end{array}$ & $\begin{array}{l}\text { Historic industry leader in community } \\
\text { development through the Rössing Foundation }\end{array}$ \\
\hline
\end{tabular}




\begin{tabular}{|c|c|c|}
\hline & $\begin{array}{l}\text { Background: } 1976 \text {, Uranium } \\
\text { mining operation in which } \\
\text { the Rio Tinto Group is the } \\
\text { majority shareholder }\end{array}$ & $\begin{array}{l}\text { and wider philanthropy. Focus on education and } \\
\text { small business development in host communities } \\
\text { and northern regions. Interventions to foster } \\
\text { sustainability of Arandis community in } \\
\text { partnership with local government. Approved } \\
\text { affirmative action plan; integrated Health, Safety } \\
\text { and Environment Management system (HSEMS); } \\
\text { Bursaries and support for Namibian Institute of } \\
\text { Mining and Technology (NIMT); Peer educator } \\
\text { and wellness programmes. }\end{array}$ \\
\hline $\begin{array}{l}\text { Rosh Pinah } \\
\text { Zinc }\end{array}$ & $\begin{array}{l}\text { Location: Rosh Pinah, Karas } \\
\text { Region } \\
\text { Background: Mine } \\
\text { constructed } 1969 \text { with Rosh } \\
\text { Pinah established as a } \\
\text { company town. Varied } \\
\text { historic ownership including } \\
\text { Incor, Kumba Resources, } \\
\text { Exxaro Resources and } \\
\text { Glencore Xstrata plc. }\end{array}$ & $\begin{array}{l}\text { OHSAS } 18001 \text { health and safety and ISO } 14001 \\
\text { HSE accreditation. Approval of affirmative action } \\
\text { plan. More ad hoc community development } \\
\text { activity and investment in Rosh Pinah township. } \\
\text { Peer educator and wellness programmes. }\end{array}$ \\
\hline
\end{tabular}

Focus groups were a secondary method of data collection, with 9 undertaken. Of those, 6 involved a translator, who in line with research best practice was fully briefed about their role and the project prior to commencement. Additionally, observation research was undertaken, and a research diary kept over the 12 month fieldwork period. Analysis of the interview and focus group data involved first transcription, and then annotation and coding utilising NVIVO data analysis software. The coding process was informed by key themes drawn from the antecedent literature but remained a largely inductive sense making process. At the time and subsequently, primary data collection was supplemented with secondary document analysis e.g. reports to stakeholders, newspaper reports etc. Limitations in the research methodology are recognised. First it was not possible to undertake research with all mining companies in Namibia, with less attention given to smaller industry actors. Nevertheless it is felt an adequate selection of companies was examined. Secondly, investment and development in Namibia's mining industry is fast changing as are advances in CSR practice and conditions on the ground e.g. legislative developments and changes in the macro-economic climate, for instance the effects of the global financial crisis and fluctuating commodity prices. Recognising this challenge every effort has been made to remain informed of local developments in the cases and industry.

\section{Mining, CSR and Sustainable Development}

Historically, and in the present, the mining industry is central to Namibia's economy. Latest industry figures estimate mining provides permanent employment for around 7898 people, with a further 478 temporary employees and 5176 contractors (Chamber of Mines Namibia 2012). In 
2012 the industry paid $\mathrm{N} \$ 1.12$ billion (US\$105.2m) in corporation tax and $\mathrm{N} \$ 957.7 \mathrm{~m}$ (US\$89.96m) in royalties, and contributed 11.5\% to Namibia's GDP (Chamber of Mines Namibia 2012). Mining has occurred in Namibia for over a century, Table 2 provides an historical overview of key events in the history of the industry. Nevertheless mining in Namibia has over time attracted considerable controversy, particularly before independence, while in the present issues like potential negative environmental implications of new mining activity (Namibian Economist, 2012), the extent of local value addition and beneficiation, and the industry's tax contribution (Namibian 2011a) remain high on the public agenda.

\section{Table 2 A History of Mining in Namibia}

\begin{tabular}{|c|c|}
\hline Year & Some key developments in mining in Namibia \\
\hline & Small scale pre-colonial mining activity \\
\hline 1905 & $\begin{array}{l}\text { Tsumeb founded by German colonial authority and copper mining commences } \\
\text { under auspices of Otavi-Minen-und-Eisenbahngesellscraft [O.M.E.G] Company }\end{array}$ \\
\hline 1908 & $\begin{array}{l}\text { Diamonds discovered on south west coast, precipitates diamond rush. Soon } \\
\text { afterwards town of Kolmanskop established. }\end{array}$ \\
\hline 1908 & Regulations enacted and diamond area declared Sperrgebiet ('Forbidden \\
\hline 1920 & territory') \\
\hline 1923 & Diamond operators merge and Consolidated Diamond Mines (CDM) formed \\
\hline 1936 & CDM granted exclusive rights for the Sperrgebiet \\
\hline 1954 & Oranjemund diamond town established \\
\hline 1969 & Kolmanskop diamond town abandoned \\
\hline 1969 & $\begin{array}{l}\text { Rosh Pinah mine built and Rosh Pinah township established } \\
\text { Founding of the Chamber of Mines Namibia, then the Association of Mining }\end{array}$ \\
\hline 1976 & Companies of South West Africa \\
\hline 1978 & Rössing Uranium mine established and Arandis township created \\
\hline 1985 & Rössing Foundation created \\
\hline 1988 & Navachab gold mine begins production \\
\hline 1990 & Okorusu Fluorspar mine begins production \\
\hline 1992 & Namibia gains its independence from South Africa \\
\hline 1994 & Minerals (Mining and prospecting) Act passed \\
\hline 1994 & Formation of Namdeb (joint ownership Government and De Beers). \\
\hline 1996 & Proclamation of Arandis and handover to state \\
\hline 1998 & Minerals Development Fund of Namibia Act passed \\
\hline 1999 & $\begin{array}{l}\text { Liquidation of Tsumeb Corporation Ltd. With significant impacts on local } \\
\text { economy and workforce. }\end{array}$ \\
\hline 2001 & Diamond Act passed \\
\hline 2001 & Skorpion Zinc Mine opens in vicinity of Rosh Pinah \\
\hline 2003 & De Beers Marine Namibia formed (joint ownership Government and De Beers) \\
\hline 2007 & First release of Minerals Policy of Namibia (Ministry of Mines and Energy) \\
\hline 2007 & Langer Heinrich Uranium mine begins production \\
\hline 2008 & Passing of Environmental Management Act \\
\hline & Epangelo Mining Company (Pty) Ltd established as state vehicle for \\
\hline 2008 & in $\mathrm{N}$ \\
\hline 2010 & Minerals Amendment Act passed relating to mining royalties \\
\hline
\end{tabular}




\begin{tabular}{|c|l|}
\hline 2011 & Namdeb Foundation formed \\
2011 & Oranjemund company town proclaimed a local authority \\
2013 & New Equitable Economic Empowerment Framework (NEEEF) released \\
& Areva Trekkopje uranium mine mothballed owing to global downward trend in \\
2015 & uranium prices. \\
$?$ & Projected completion date of the Husab uranium mine \\
\hline
\end{tabular}

\subsection{Making 'ghost towns'? CSR and mining community sustainability}

Company towns, defined by Lucas (1971) as communities owned and administered by an industrial employer, have historically been a feature of the mining landscape in Namibia. Examples include the diamond towns of Kolmanskop and Oranjemund, Arandis, Rosh Pinah and Uis amongst others. The preponderance of these kinds of community in Namibia and their distribution is attributable to geographical and historical factors. Nambia's mineral resources are largely located in remote and underpopulated parts of the country e.g. the Karas Region, necessitating the construction of new settlements to house mine employees. However, Namibia's population geographies are also informed by policies during the country's occupation by South Africa which sought to concentrate non-white Namibians in Bantustan 'homelands', particularly the present day north central regions of Omusati, Ohangwena, Oshana and Oshikoto. The mining industry drew extensively upon these regions for its labour. In existing discussions of both company towns, but also compounds/hostels, it has been suggested that companies adopted such approaches as a mechanism for labour control and the maintenance of stable operating environments (Crush, 1994). However, company towns with high quality health and education facilities were also beneficial for attracting and retaining skilled employees. In recent times, and reflecting global trends, mining companies in Namibia have moved away from operational models requiring the creation of company towns. Mining developments like the Skorpion Zinc mine, have where possible adopted long-distance commuting (LDC) employment policies or sought to house employees in existing settlements. Nevertheless, some company towns still exist, and in Namibia like elsewhere, what happens to company towns when mining ceases or during periods of low commodity prices remains a significant sustainable development challenge.

In Namibia during periods of sustained low commodity prices, or as resource profiles decline, company towns have frequently been handed over to the State. For example Arandis was handed over and proclaimed a local authority in 1994, while more recently in 2011 Oranjemund was handed over by Namdeb. Littlewood (2014) identifies four key areas of challenge actors in such communities face in efforts to foster their sustainability and viability including: (1) Challenges of dependency, e.g. the reliance of local businesses, people, infrastructure on mine 
subsidies; (2) Challenges of location, the remote physical location of these communities; (3) Challenges of community, for example many people reside in these communities purely for work or are economic migrants and may have no long term desire to remain; (4) Challenges of purpose, what is the purpose of these communities after mining. In Namibia these types of community have struggled following proclamation and as mining activity is reduced, for example Arandis entered a period of almost terminal decline following proclamation and as the nearby Rössing Uranium mine contracted, as illustrated by the following interview quotation:

They have to have end game in place. While everything is fresh in peoples' minds about how close Arandis came to being a ghost town. (Interview local government representative)

Such difficulties have also been faced by Oranjemund since proclamation, for example in the Namdeb 2009 Annual Review it states that 'Oranjemund almost became a ghost town'.

To varying extents the case study companies have engaged through CSR with the issue of community sustainability and viability. For example, in 2005 the Rössing Foundation opened an office in Arandis recognising the risks associated with the community's decline including reputational damage, threats to its 'licence to operate', and instability in its operating environment e.g. employees living in a community lacking adequate services. Thereafter, the Foundation and company began working with local government and key stakeholders in partnership through the Arandis Sustainable Development Project (ASDP). Interventions have included: capacity building for the local authority; educational interventions to make Arandis an 'educational town of choice'; funding for consultancy and infrastructure repair and upgrading (particularly water); and support for local business. In the case of Oranjemund, Namdeb has funded feasibility surveys examining alternative economic activities, provided training, support and loans for local businesses, and continues to subsidise local education and health provision. In Rosh Pinah company support has been somewhat more ad hoc but has focussed on similar themes.

Viewed in isolation such activities suggest a significant commitment and contribution on the part of the case companies to the sustainability and development of these communities. However, analysis of such activities must be balanced with the role the companies have played in creating these communities, and their long term sustainability challenges. Historic relationships between the mining companies and such communities have been characterised by unsustainability. These communities were built to provide companies with stable operating environments. The high quality and mostly private health and education infrastructure in them were constructed to meet company needs. Accordingly as mining operations contract such 
facilities are often no longer viable and have been handed over to the state and downgraded, as occurred to the Rössing hospital in Arandis. The decision by mining companies to advocate for the handover of these communities raises questions in relation to trade-offs e.g. handover has significant economic benefits for companies but potential social costs for current and future community residents and Namibia's government, which as illustrated by the following quotation may have to subsidise such unsustainable communities:

They couldn't maintain the infrastructure the water and the electricity they couldn't pay for it they couldn't generate enough money to be viable and sustainable... what you will have is a failure and the government will have to come in and subsidise these things. (Interview national government representative)

The current dispensation around company towns in Namibia raises questions about the extent sustainable development is fully embedded within mining company business models, decision making and strategy, and about the potential for past unsustainable practices to have present day and future material implications e.g. mining companies in Namibia are now moving away from company town operational models. It furthermore raises questions about power relations between the state, mining companies and the wider mining industry, as the final decision on handover is still made by Namibia's government.

\subsection{Relationships in Community Development}

Community development by mining companies in Namibia has evolved over time, driven by institutional change in Namibia and neighbouring South Africa (Hamann, 2004), and advances in global industry best practice. Approaches have also varied amongst the cases and industry as a whole. Some companies have favoured the establishment of in-house development projects, while others have created dedicated semi-autonomous foundations. In other instances social funds channel donations through partners, while some companies are providing soft loans and business support, frequently with the aim of integrating local companies into their supply chains. Companies often utilise several of these approaches.

Rössing Uranium through its Foundation has historically been an industry leader in community development. This is illustrated by the following interview quotation, and also reflected in other industry actors (Namdeb and Anglo-American Namibia) recently launching similar semiautonomous foundations for their community work:

That is really the problem, and we are hoping that the company needs to really rethink its social responsibility policies. Similar to what the Rössing Foundation is doing. (Interview CSR 
Manager)

Some strengths of the Rössing Foundation's recent work include: that it has been undertaken in collaboration with government and civil society partners; that a more strategic approach has been adopted, with interventions working in combination rather than 'silo' isolation; clear shared goals and objectives have also been defined, with mechanisms for assessing progress; and effort has been expended to foster stakeholder beneficiary participation and ownership. The Rössing Foundation's educational interventions illustrate the importance of strong relationships with recipient communities and development partners. The Rössing Foundation has sought to contribute to 'whole school development' by complimenting government activities within the framework of Namibia's Education and Training Sector Improvement Programme, for example the Foundation and state have agreed and signed a Memorandum of Understanding outlining their respective roles and areas of activity. While an important strand of the Foundation's support for education has been the physical construction of three Mathematics, English and Science centres utilised by local schools, interventions have also included teacher support and development, and regional education capacity building. In its 2012 Report to Stakeholders, the Rössing Foundation recognises that there is still room for improvement in its educational interventions, and that the educational challenges faced are substantial and deep-rooted. Nevertheless, current more relational approaches are a positive development, and this is again reflected in other mining companies in Namibia adopting similar methodologies in their community development activities.

While the Foundation's recent educational work illustrates improving industry community development practice, these activities are still susceptible to sustainability concerns, particularly with current low global uranium prices. The challenge of sustainability is one faced by the Foundation before e.g. many education centres run by the Foundation located across Namibia were handed over to partners in the 1990s during a period of sustained low global uranium prices. This issue can also be illustrated with reference to an in-house skills training centre, run from 2000-2005 by another case study. As illustrated by the following quotation the Centre was heavily reliant on company funding with little contingency in place for lean periods, more recently the Centre has been run by the local town management company:

Yes I think that it could not go on because they ran the Centre like it is a part of the mine. So they give everything, and everything we wanted to use had to come from the mine office (Interview Former Centre Staff Member) 
These threats reinforce the need for community development activities to be founded upon strong relationships with partners and communities. Although, another important group of relationships are those between different mining companies, particularly when operating in close proximity e.g. the Rosh Pinah Zinc Corporation and Skorpion Zinc cases. In interviews it was discussed that competition between companies could result in resource inefficiencies and potential for duplication in community development, as illustrated by the following quotation:

Because if there are two schools there would be too many schools for a small community, that's not the way that we should be looking at it... until recently that is not really happening there is no consultation you just hear (clicks fingers) that they have done this (Interview CSR Manager)

Conversely, in other instances where companies collaborate on community development e.g. where Namdeb, Skorpion Zinc and the Rosh Pinah Zinc Corporation collaborated on the building of a border checkpoint, the potential for cumulative impacts is considerable.

A final perspective on community development, particularly in a historical sense, relates to criticism that it is just 'greenwash'. A strong case could be made that before Namibia's independence even CSR community development leaders juxtaposed such activities with wider irresponsible business practices, for instance: the use of migrant labour; poor health and safety; racial discrimination in the terms and conditions of employment; negative environmental impacts; and what were described as 'ridiculously low' rates of taxation (see Kempton \& Du Preez, 1997). In the present, it might be argued that whilst mining companies have become more proficient in such development interventions, concerns remain about their wider activities and embedded relationships in Namibia e.g. tax avoidance issues, government lobbying, and limitations in local value addition and beneficiation.

\subsection{CSR, Mining and the Environment}

In interviews it was commented that whist mining was widely viewed as 'the cornerstone' of national growth and development, that its destructive side, particularly for the environment, was frequently overlooked. The historic negative implications of mining for the environment in Namibia have been widely discussed. For example, in a key study Barnard (1998) documents the widespread national problem of mine abandonment and non-rehabilitation, and associated issues of pollution to water sources, biodiversity loss, stresses to sensitive ecosystems, visual pollution, and danger to human safety and health. The Chamber of Mines Namibia (2010) estimates there are over 200 abandoned mines in the country, with liability for their rehabilitation transferred to the State. This environmental issue therefore also has significant social and development implications, as the costs of mining's historical externalities are 
transferred to Namibia's people and government. An illustrative historical example of this problem is the case of Tsumeb Corporation Ltd (TCL) which closed in 2001. Reichardt (2003) reports that due diligence by prospective new operators revealed only $30 \%$ of the true closure cost requirement had been set aside by TCL. Whilst in the present the environmental impacts of over 100 years of copper mining in and around Tsumeb are still being unearthed (Namibian, 2014).

Historic environmental problems relating to mining in Namibia in part reflect the weak governance of the industry prior to independence, but also the slow progress made by Namibia's Government after independence in enacting new stronger environmental legislation, as well as limits in their ability to ensure compliance. It was only in 2007, that a comprehensive Environmental Management Act was introduced, and in 2012 that the Act fully came into operation. However, despite recent legislative developments, negative environmental impacts from mining are not only a legacy issue. In the present, ensuring that current mining operators adequately provision with 'real money in the bank' for after-mining rehabilitation remains a challenge. Whilst some companies have established trust funds to ensure liabilities are met others have not. In some interviews it was suggested that at a macro level, mining and its perceived national economic benefits were prioritised and to an extent overrode environmental concerns. This view and problems relating to mineral extraction in sensitive areas are illustrated in the following interview quotation:

The mines and energy act override all other acts in the country. If they discover they can mine petroleum in the middle of the Sperrgebiet then it will be, because that gives you more economic development than tourism does and scenery does ... right up the Skeleton Coast it is the same situation. You have got guys right in the Kunene Mouth (Interview Local Environmental Advocate)

Small-scale mining operators failing to abide with environmental legislation is a significant problem in Namibia, and in interviews it was suggested that lack of government resources and capacity made policing such activities difficult, while until recently regulatory limitations meant state actors 'could not use a stick to go and beat them'. However, there are also environmental challenges relating to larger operators. Many older larger mines face issues of retroactivity e.g. as Namibia's legislation and/or social expectations around environmental responsibility have become stricter, their original closure/rehabilitation plans and operating practices may no longer be sufficient. An illustration of this challenge can be seen at the Rosh Pinah Zinc mine which during the fieldwork was grappling with the issue of air pollution and dust blown from its 
tailings/slimes dam:

There are more and more people coming from the community, guys who come up and say what is the plan with the slimes dam ... some of the ladies did not want to stay in Rosh Pinah because of the dust (Interview Mine Representative)

Environmental problems like this also have social and development implications, with generally the poorest in society most exposed to environmental pollution and related health consequences.

However, it is not only older mines that are environmentally contentious. For instance there has been considerable recent public debate around the 'uranium rush' and commissioned and potential new uranium mines opening in Namibia's Erongo region (e.g. the Areva Trekkopje Mine, and Swakop Uranium Husab Project), as well as potential expansion of existing mines (Rössing Uranium). While uranium mining expansion in the region has been scaled back in response to falling global uranium prices, there nevertheless remain significant environmental challenges associated with such developments, which have to be managed, including: competing demands for water and the potential over-exploitation of groundwater; damage to habitats, loss of biodiversity and disruption of ecosystem processes; impacts to dust and air quality from mining activity and transport; increased energy demands (for more detail SAIEA 2011). In interviews it was suggested that the successful management of these challenges required mining companies to develop strong relationships with other companies and the state e.g. in the Erongo region joint planning around the construction of water desalinisation plants, but also reciprocal relationships with communities and wider stakeholders based on genuine respect, transparency and dialogue. While undoubtedly such ideal type relationships are desirable, questions remain about the power dynamics experienced in such relationships in a Namibian context, including the extent that local opposition and civil society environmental advocacy might curtail mining expansion or hold mining companies to account for externalities. For further discussion of these issues see the Forsys Valencia Uranium Mine case study (Stanford Law School, 2009). These developments will likely require a trade-off between economic and social imperatives versus environmental concerns, and only time will tell whether this is in the long term sustainable development interests of Namibia and its people.

\subsection{CSR, Politics and Mining Governance}

In recent years increasing academic attention has been devoted to what is being termed political CSR (Scherer \& Palazzo, 2011), with critical works also addressing subjects like: the limits of CSR as self-regulation (Banerjee, 2008); corporate social accountability (Sethi, 2008); 
and corporate political lobbying and tax avoidance (Christensen and Murphy, 2004). A further frequent criticism of CSR is that it often focuses on the micro-level e.g. local community development, eschewing consideration of macro level concerns relating to overall MNC activity and relationships (Gulbrandsen and Moe, 2007). Applying a more relational, macro level perspective to CSR in the mining industry in Namibia raises various questions. In particular, while mining has and continues to play a central role in Namibia's economy, in totality, given Namibia's pressing development needs e.g. high levels of poverty, inequality, unemployment, HIV/AIDS prevalence, low skills, etc. is the mining industry doing enough? Furthermore, is voluntary CSR the best way to ensure this contribution?

Criticism in this respect might be most readily applied to mining in Namibia prior to independence, with the legacies of this period ongoing (Kempton and Du Preez, 1997). However, in the present, while mining is no longer as contentious, the industry's overall national sustainable development contribution remains much debated. For example in 2011 Namibia's Minister of Mines and Energy charged that the country had become an "Eldorado of speculators and other quick-fix, would-be mineral explorers and mining developers" (Namibian, 2011a). On the subject of value addition and beneficiation other ministers (Namibian, 2010), regional governors (Namibian, 2011b) and even the President (Namibian, 2012) have also variously admonished and demanded improvement from the industry. Criticism in relation to empowerment of previously disadvantaged Namibians, employment opportunities, employment terms and conditions and tax contributions (particularly for companies with contentious Export Processing Zone status, see Jauch, 2002), has also come from national trade union and youth leaders. Some sections of civil society have also been critical, for example Shindondola-Mote (2009) in discussion of the implications of uranium mining in Namibia, particularly for community and employee health, concludes that 'in Namibia mining has short term benefits, but long term consequences' (pp. 51).

However, on the other side, mining advocates point to: mining company tax contributions; to the direct and indirect employment created by the industry and wider dependents supported; to wage spending and procurement from local businesses; improving environmental and stakeholder relationships; and community development activities. Advances in many of these areas have also been voluntarily driven through CSR, as part of a suggested 'embedding' of CSR and sustainable development throughout company value chains and relationships. Examples of such embedding and pre-empting of legislation include: (1) the industry initiated Namibian Preferential Procurement Council, launched in 2003 by three southern mines in the context of a delay in government empowerment policy. It was only in 2011/12 that the New Equitable 
Economic Empowerment Framework (NEEEF) was released and enacted; (2) the 2010 Namibian Mine Closure Framework, devised through the Chamber of Mines Namibia in response to policy and legislative weaknesses around mine closure; (3) the industry proposed Strategic Environmental Impact Assessment (SAIEA 2011) of uranium developments in central Namibia.

Unravelling these contrasting perspectives on the role of mining and CSR in sustainable development in Namibia is difficult. Certainly there have been advances in best practice and social and environmental performance, and it might also be questioned what responsibility Namibia's government has in legislating mining companies, and when faced with issues like community handover adopting a more critical long-term perspective in decision-making. However, a recent example again raises the issue of power relations and potential imbalances, this time between the state and the mining industry and international investors. In line with trends on the rest of the Continent and globally, taxation, royalties and levies on mining have been an increasing source of tension between the industry and government in Namibia. In 2006 new mining royalties were introduced, but faced with industry opposition and in some instances non-payment, the royalty rates were amended and reduced. More recently, in 2012 Namibia's Government proposed a 5\% export levy on raw materials (including minerals). Again industry lobbying, opposition and threats of disinvestment and mine closure have seen the levies fall to $0-2 \%$.

This case highlights the significant sway of the mining industry in politics and resource governance in Namibia, and also limits in relation to what is generally considered in CSR agendas e.g. corporate political lobbying. The Namibian Mine Closure Framework could also be read as another example of this, for instance it does not provide guidance on the rehabilitation of abandoned mines, closure guidelines for small scale mines, nor significantly engage with the issue of company towns and their hand-over, despite the importance of these issues in the Namibian mining context. Current conceptions of CSR and its practice in Namibia's mining industry are strongly underpinned by an emphasis on the 'business case' (Carroll and Shabana, 2011 ) and 'win win' outcomes for engagement with sustainable development issues, described by one interviewee as 'a selfish responsibility'. This serves to limit the CSR agenda, and its potential as a vehicle for transformative change in the country's mining industry towards the prioritisation of human-centric, pro-poor sustainable development proposed in the original Bruntland definition.

\section{Conclusions}

This paper has explored the nexus of CSR and sustainable development in the context of mining 
in Namibia and through a relational lens. Their intersection has been unpacked drawing upon empirical research with four case study mining companies, and reflecting on four significant CSR issues: (1) mining community sustainability and viability; (2) community development activities; (3) CSR and the environment; (4) politics and governance issues. In the introduction two research questions were proposed. In relation to the first, a varied picture was found in terms of congruence between CSR and sustainable development. While instances of better practice in community development, environmental management, and stakeholder relationships were observed, limitations were also found in current manifestations of CSR as a vehicle for pro-poor human-centric sustainable development. The second question related to the application of a relational lens, with such an approach and focus on relationships woven throughout discussions in this paper. The benefits of such an approach include significant appreciation of temporal dimensions of corporate responsibility, which are important in Namibia. While more spatial aspects of corporate responsibility are also reflected upon e.g. greater appreciation of the overall implications of mining for Namibia, and for instance how communities throughout the country may be affected by mine closure (particularly if it is badly managed), how tax avoidance or limited value addition can constrain national development and poverty alleviation efforts, or how the cost of mining liabilities and externalities can be transferred to Namibia's government and tax payers, for example mine rehabilitation or subsidising unsustainable former mining communities.

This paper contributes to knowledge, policy and practice. It adds to hitherto limited work on mining, CSR and sustainable development in Namibia, with salience for understanding issues around this in other countries in Africa and the wider developing world. Its empirical basis and focus on Namibia's whole mining industry is also relatively unusual. In applying a critical relational lens and focussing on relationships this study also combines perspectives from management and human geography in a relatively new way, with scope for further development, for example applying such an approach to other industries and countries, and developing a more defined conceptual model of a relational approach to CSR. This research also provides insights for policy in highlighting some of the limits of current incarnations of CSR in Namibia, potentially necessitating further state intervention. Some positive examples of CSR community development activity, environment and stakeholder management have also been outlined with potential insights for practitioners, for instance it has been argued that the creation of reciprocal relationships and partnerships with other businesses, civil society actors, communities and state actors are crucial for success.

\section{References}


Armstrong A, 2006. Ethical issues in water use and sustain-ability. Area 38, 9-15

Atkins, P, Manzurul, HM \& Dunn, C, 2006. Toxic torts: arsenic poisoning in Bangladesh and the legal geographies of responsibility, Transactions of the Institute of British Geographers 31, 272-85

Barkemeyer, R, Holt, D, Preuss, L \& Tsang, S, 2014. What Happened to the "Development" in Sustainable Development? Business Guidelines Two Decades After Brundtland, Sustainable Development, 22, 15-32. doi: 10.1002/sd.521

Banerjee, SB, 2008. Corporate Social Responsibility: The Good, the Bad and the Ugly, Critical Sociology 34(1), 51-79.

Barnard, P, 1998. Biological diversity in Namibia, Namibian National Biodiversity Task Force.

Bebbington, A, Hinojosa, L, Bebbington, DH, Burneo, ML \& Waarnars, X, 2008. Contention and Ambiguity: Mining and the Possibilities of Development. Development and Change 39(6), 887-914.

Campbell, B, 2012. Corporate Social Responsibility and development in Africa: Redefining the roles and responsibilities of public and private actors in the mining sector, 37(2), 138-143.

Carroll, AB, 1999. Corporate Social Responsibility Evolution of a Definitional Construct. Business and Society, 38(3), 268-295.

Carroll, AB \& Shabana, KM, 2009. The Business Case for Corporate Social Responsibility: A Review of Concepts, Research and Practice. International Journal of Management Reviews 12(1), 85105.

Chamber of Mines Namibia, 2010. Namibian Mine Closure Framework.

Chamber of Mines Namibia, 2012. Chamber of Mines Namibia Annual Review 2012: http://www.chamberofmines.org.na/main/publications/annual-reports.html Accessed 8 March 2014.

Christensen, J \& Murphy, R, 2004. The social irresponsibility of corporate tax avoidance: taking CSR to the bottom line. Development 47(3), 37-44.

Chronjé, F \& Chenga, CS, 2009. Sustainable social development in the South African mining sector. Development Southern Africa 26(3), 413-27.

Claasen, C \& Roloff, J, 2012. The Link between Legitimacy and Responsibility. The Case of DeBeers in Namibia. Journal of Business Ethics 107(3), 379-398.

Corbridge, S, 1998. Development ethics: difference distance and plausibility, Ethics Place and Environment 1, 35-53.

Crush, J, 1994. Scripting the compound: power and space in the South African mining industry. Environment and Planning D: Society and Space 12(3), 301 - 324

Ely, A, Smith, A, Stirling, A, Leach, M \& Scoones, I, 2013, 'Innovation politics post-Rio+20: hybrid 
pathways to sustainability?' Environment and Planning C: Government and Policy 31(6) 1063 $-1081$

Gulbrandsen, LH \& Moe, A, 2007. BP in Azerbaijan: A test case of the potential and limits of the CSR agenda. Third World Quarterly 28(4), 813-30.

Hamann, R, 2003. Mining companies' role in sustainable development: The 'why' and 'how' of corporate social responsibility from a business perspective. Development Southern Africa 20(2), 237-54.

Hamann, R, 2004. Corporate social responsibility, partnerships, and institutional change: The case of mining companies in South Africa. Natural Resources Forum 28(4), 278-90.

Hamann, R \& Kapelus, P, 2004. Corporate Social Responsibility in Mining in Southern Africa: Fair Accountability or just Greenwash? Development 47(3), 85-92.

ICMM (2014) International Council on Mining \& Metals: http://www.icmm.com/ Accessed 8 March 2014.

Jauch, $\mathrm{H}, 2002$. Export processing zones and the quests for sustainable development: a Southern African perspective, Environment and Urbanization 14(1), 101-113.

Kapelus, P, 2002. Mining Corporate Social Responsibility and the 'community': The case of Rio Tinto Richards Bay Minerals and the Mbonambi. Journal of Business Ethics 39(3): 275-96.

Karamata, HN, 2009. Corporate Social Responsibility at Namdeb Diamond Corporation: An Exploratory Case Study. Unpublished MBA thesis, University of Stellenbosch.

Kemp, D, 2009. Mining and community development: Problems and possibilities of local level practice. Community Development Journal 45(2), 198-218.

Kempton, DR \& Du Preez, RL, 1997. Namibian De Beers State Firm Relations: Co-operations and Conflict. Journal of Southern Africa Studies 23(4), 585-613.

Kitchen, R, \& Tate, NJ, 2000. Conducting research into human geography, Prentice Hall, Harlow, Essex.

Kolk, A \& Lenfant, F, 2012. Business-NGO Collaboration in a Conflict Setting: Partnership Activities in the Democratic Republic of Congo. Business and Society 51(3), 478-511.

Lindgreen, A \& Swaen, V, 2010. Corporate Social Responsibility. International Journal of Management Reviews 12(1), 1-7.

Littlewood, D, 2014. 'Cursed' Communities? Corporate Social Responsibility (CSR), Company Towns and the Mining Industry in Namibia, Journal of Business Ethics 120(1), 39-63.

London, T \& Hart, SL, 2010. Next generation business strategies for the base of the pyramid: New approaches for building mutual value. FT Press.

Lucas, RA, 1971. Minetown, Milltown, Railtown: Life in Canadian Communities of Single Industry. University of Toronto, Toronto. 
Lungu J. 2008. Socio-economic change and natural resource exploitation: a case study of the Zambian copper mining industry, Development Southern Africa 25(5), 543-560.

Mason, L, Prior, T, Mudd G \& Giurco, D, 2011. Availability, addiction and alternatives: three criteria for assessing the impact of peak minerals on society. Journal of Cleaner Production 19(9/10), 958-966

Massey, D, 2004. Geographies of Responsibility. Geografiska Annaler 86(1), 5-18.

Namibian, 2008. African civil society hits back at uranium mining: http://www.namibian.com.na/indexx.php?archive id=48555\&page type=archive story det ail\&page=3306 Accessed 8 March 2014.

Namibian, 2010. Tighter control on resources needed: Nahas: http://www.namibian.com.na/indexx.php?archive id=64704\&page type=archive story det ail\&page $=2$ Accessed 8 March 2014.

Namibian, 2011a. Katali lays into foreign miners, accessed: http://www.namibian.com.na/indexx.php?archive id=79587\&page type=archive story det ail\&page=2 Accessed 8 March 2014.

Namibian, 2011b. Swartbooi diamond policy factory in Karas: http://www.namibian.com.na/indexx.php?archive id=87090\&page type=archive story det ail\&page=1 Accessed 8 March 2014.

Namibian, 2012. In Need Of An Action Plan!: http://www.namibian.com.na/indexx.php?archive id=92147\&page type=archive story det ail\&page=1 Accessed 8 March 2014.

Namibian, 2014. Research highlights, severe pollution from mining: http://www.namibian.com.na/indexx.php?id=10110\&page type=story detail Accessed 8 March 2014.

Namibian Economist, 2012. Namibia: Mining Poses Many Environmental Risks. http://allafrica.com/stories/201206230095.html Accessed 8 March 2014.

Noxolo, P, Raghuram, P \& Madge, C, 2011. Unsettling responsibility: postcolonial interventions. Transactions of the Institute of British Geographers 37(3), 418-429.

OP, 2004. Office of the Prime Minister, Vision 2030.

Owen, JR \& Kemp, D, 2012. Assets, Capitals and Resources: Frameworks for Corporate Community Development in Mining. Business and Society 51(3), 382-408.

Perks, R, 2012. How can public-private partnerships contribute to security and human rights policy and practice in the extractive industries? A case study of The Democratic Republic of Congo (DRC), Resources Policy 37(2), 251-260.

Porter, ME \& Kramer, MR, 2011. Shared value: How to reinvent capitalism—and unleash a wave 
of innovation and growth. Harvard Business Review 89(1/2), 62-77.

Power, M, 2009. The Commonwealth, 'development' and post-colonial responsibility Geoforum $40,14-24$.

Prno, J \& Slocombe, DS, 2012. Exploring the origins of 'social license to operate' in the mining sector: Perspectives from governance and sustainability theories. Resources Policy, 37(3), 346-357.

Reichardt, M, 2003. Potentially Uncovered Liabilities- the problem of a fragmented approach to Mine Closure Trust Funds in RSA, Chamber of Mines South Africa.

Rittel, H \& Weber, M, 1973. Dilemmas in a general theory of planning. Policy Sciences 4, 155169.

SAIEA (2011) Southern African Institute for Environmental Assessment - Strategic Environmental Assessment for the central Namib Uranium Rush: http://www.saiea.com/uranium/ Accessed 8 March 2014.

Seechi, D, 2007. Utilitarian, managerial and relational theories of corporate social responsibility. International Journal of Management Reviews 9(4), 347-373.

Sethi, SP, 2008. Defining the concept of good corporate citizenship in the context of globalization: a paradigm shift from corporate social responsibility to corporate social accountability, in Scherer, A. G. \& Palazzo, G. (Eds), Handbook of Research on Global Corporate Citizenship. Cheltenham: Edward Elgar, 74-98.

Seuring SA, Koplin J, Behrens T \& Schneidewind, U, 2003. Sustainability assessment in the German detergent industry: from stakeholder involvement to sustainability indicators. Sustainable Development 11(4), 199-212.

Scherer, AG \& Palazzo, G, 2011. The New Political Role of Business in a Globalized World: A Review of a New Perspective on CSR and its Implications for the Firm, Governance, and Democracy 48(4), 899-931.

Shindondola-Mote, H, 2009. Uranium mining in Namibia: The mystery behind 'low level radiation, Labour Resource and Research Institute (LaRRI): Windhoek.

Smith, D M, 2000. Moral Geographies Ethics in a World of Difference, Edinburgh University Press.

Stanford Law School 2009, Not coming up dry: regulating the use of scarce water resources by mining operations, report prepared by Stanford Law School in association with the Legal Assistance Centre (LAC) Namibia.

Terrachoice, 2014. The sins of greenwashing: home and family edition: http://sinsofgreenwashing.org/ Accessed 8 March 2014.

Wan, PMJ, 2014. Environmental justices and injustices of large-scale gold mining in Chana: A study of three communities near Obuasi, the Extractive Industries and Society, in press. 
WCED (ed.), 1987. Our Common Future: The World Commission on Environment and Development, Oxford University Press: Oxford.

Williams, A, 2011. Shining a Light on the Resource Curse: An Empirical Analysis of the Relationship between Natural Resources, Transparency, and Economic Growth, World Development 39(4), 490-505.

Yin, R. K. (2009) ‘Case Study Research: Design and Methods 4th Edition’, Barnes and Noble. 